\title{
Article \\ Primary Characterization of a Life-Cycle Mutant akasusabi of the Red Alga Neopyropia yezoensis
}

\author{
Koji Mikami ${ }^{1, *(D)}$, Takaharu Matsumura ${ }^{2,3}$ and Yuji Yamamoto ${ }^{2,4}$ \\ 1 Department of Food Resource Development, School of Food Industrial Sciences, Miyagi University, \\ 2-2-1 Hatatate, Taihaku-ku, Sendai 982-0215, Japan \\ 2 Marine Resources Research Center of Aichi Fisheries Research Institute, 2-1 Toyoura, Toyohama, \\ Minamichita-cho, Chita 470-3412, Japan; matsumura-ta906@pref.miyagi.lg.jp (T.M.); \\ yuuji_4_yamamoto@pref.aichi.lg.jp (Y.Y.) \\ 3 Aichi Fisheries Research Institute, 97 Wakamiya, Miya-cho, Gamagori 443-0021, Japan \\ 4 Fisheries Administration Division, Aichi Prefectural Government, 3-1-2 Sannomaru, Naka-ku, \\ Nagoya 460-8501, Japan \\ * Correspondence: mikamik@myu.ac.jp
}

Citation: Mikami, K.; Matsumura, T.; Yamamoto, Y. Primary

Characterization of a Life-Cycle Mutant akasusabi of the Red Alga Neopyropia yezoensis. Phycology 2021, 1, 14-26. https://doi.org/10.3390/ phycology1010002

Academic Editor: Assaf Sukenik

Received: 5 June 2021

Accepted: 19 July 2021

Published: 25 July 2021

Publisher's Note: MDPI stays neutral with regard to jurisdictional claims in published maps and institutional affiliations.

Copyright: (C) 2021 by the authors. Licensee MDPI, Basel, Switzerland. This article is an open access article distributed under the terms and conditions of the Creative Commons Attribution (CC BY) license (https:/ / creativecommons.org/licenses/by/ $4.0 /)$.

\begin{abstract}
Gametophyte-to-sporophyte transition in the haploid-diploid life cycle depends on fertilization of male and female gametes. We describe here a mutant of the marine red seaweed Neopyropia yezoensis, designated akasusabi (aks), where the gametophyte-to-sporophyte transition occurs independently of fertilization. Although conchocelis filaments were produced from carpospores, severe defects in the maturation of carposporangia via mitosis to generate conchospores were observed. In the aks mutant, however, somatic cells of gametophytic thalli were able to produce conchocelis filaments without fertilization. Thus, apogamy occurs in aks. In addition, aks was highly sensitive to wounding that promotes both asexual and apogamous reproductive responses by producing spores, which develop either into blades or conchocelis filaments, indicating that aks responds to wounding by enhanced reproduction. These findings indicated that the aks mutation enables the transformation of vegetative cells to carpospores to produce sporophytes by apogamy and wound-inducible life cycle trade-off, stimulating a reset of the timing of reproduction during the life cycle. Therefore, AKS is involved in regulations of the gametophyte-to-sporophyte transition and asexual spore production in N. yezoensis.
\end{abstract}

Keywords: akasusabi; apogamy; life cycle; Neopyropia yezoensis; reproduction; wound stress

\section{Introduction}

Life cycles in plants consist of diploid sporophyte and haploid gametophyte $[1,2]$. Similarly, life cycles of the red algae of the Bangiales are diphasic, with haploid leafy gametophyte (thallus) and diploid filamentous sporophyte (conchocelis) [3,4], as first established by Drew [5]. In general, meiosis and fertilization trigger the transitions from sporophyte to gametophyte and from gametophyte to sporophyte, respectively, in plants and algae $[2,6,7]$. Indeed, the transition from gametophyte to sporophyte in Bangiales is triggered by fertilization of male and female gametes, which promotes the development of a carposporangium from the fertilized female gamete on gametophytic thalli [4]. Then, the carposporangium produces unicellular carpospores via mitotic cell division, which upon release, generate conchocelis filaments as sporophytes [4]. Thus, production of carpospores in the carposporangium via fertilization of gametes is tightly linked to the gametophyte-to-sporophyte transitions in the life cycle of Bangiales.

In the sporophyte-to-gametophyte transition in Bangiales, development of gametophytic thalli starts from unicellular conchospores released from conchosporangia parasitically produced on conchocelis filaments [4]. However, meiosis occurs during the early development of gametophytic conchospores in Bangiales [8-17]. Thus, gametophyte identity of the conchospore could be established during maturation of the conchosporangium 
in a meiosis-independent manner in Bangiales, which is different from the general concept of a meiosis-dependent sporophyte-to-gametophyte transition [1,2]. Recently, we have shown that the production of conchospores in conchosporangia depends on apospory, which is a process producing diploid gametophytes from the diploid generation without meiosis [18-20], in the marine red macroalga Neopyropia yezoensis (formerly Pyropia yezoensis) [21]. Moreover, since physiological and genome-wide gene expression analyses indicated that conchosporangium is one of the life cycle generations, it was renamed conchosporophyte, by which the life-cycle strategy of Bangiales was hypothesized as triphasic [21]. Based on these findings, generation transitions from sporophyte to conchosporophyte and conchosporophyte to gametophyte might be regulated in unique ways in Bangiales, whereas the gametophyte-to-sporophyte transition depends on fertilization as in both red seaweeds and terrestrial plants.

It is unknown whether the regulatory mechanism of the fertilization-dependent gametophyte-to-sporophyte transition is conserved between red seaweeds and terrestrial plants. Recently, life-cycle mutants proved useful in elucidating the regulators involved in the generation transition in brown seaweeds. The mutants ouroboros (oro) and samsara (sam) are defective in the regulation of the gametophyte-to-sporophyte transition in the model brown seaweed Ectocarpus siliculosus, and the genes responsible for these mutations were identified [22,23]. However, no life cycle mutants have been reported in Bangiales, although a bisexual mutant has been isolated in Gracilaria tikvahiae of Florideophycidae [24,25]. Isolation of life-cycle mutants from Bangiales is, therefore, one of the strategies for elucidating the regulatory mechanisms of generation transition in red seaweeds.

We describe here a red-colored high-growth mutant obtained from N. yezoensis. In this mutant, sporophytes developed directly from vegetative somatic cells or somatic cellderived spores because of defects in mitosis in the carposporangium to produce carpospores, which in turn, inhibited production of sporophytes via carpospores. In addition, wounding stress increased the production of spores developing to sporophytes or gametophytes. These findings indicate that it is the first life-cycle mutant of red seaweeds and the genes responsible for this phenotype that are involved in both gametophyte-to-sporophyte transition and asexual reproductive processes.

\section{Materials and Methods}

\subsection{Isolation of a Mutant}

A red-colored mutant naturally appeared, rather than being artificially generated, during experimental aquaculture of gametophytes of the N. yezoensis wild type (WT; strain U51) in the Marine Resources Research Center of Aichi Fisheries Research Institute in Toyohama, Aich, Japan, in 2011. It was isolated and maintained in the laboratory (see below) to analyze its morphological and physiological characteristics.

\subsection{Algal Strain, Culture Conditions and Calculation of the Growth Rate}

Gametophytic blades of the WT and the mutant of N. yezoensis were cultured in sterilized artificial seawater (SEALIFE; Marinetech, Tokyo, Japan) containing ESS 2 with $\mathrm{NaNO}_{3}$ as a nitrogen source, along with vitamins and trace metals [26]. The samples were cultured under $60-70 \mu \mathrm{mol}$ photons $\mathrm{m}^{-2} \mathrm{~s}^{-1}$ as an optimal photon flux density in a shortday photoperiod $\left(10 \mathrm{~h}\right.$ light $/ 14 \mathrm{~h}$ dark) at various temperatures $\left(0,4,10,15,20\right.$ and $\left.25^{\circ} \mathrm{C}\right)$, before being aerated with air filtered through a $0.22-\mu \mathrm{m}$ filter (Whatman; GE Healthcare, Chicago, IL, USA). The culture medium was changed weekly. The growth rates of WT and the mutant were calculated by dividing the lengths of germilings $(\mathrm{cm})$ of asexually released monospores by the duration of incubation (day) under $0,4,10,15,20$ and $25^{\circ} \mathrm{C}$ for $4,11,15,21,28$ and 36 days.

\subsection{Quantitative Measurement of Photosynthetic Pigments}

Chlorophyll a (Chl a) was separately extracted from each sample with Dimethyl sulfoxide (DMSO) and then with $90 \%$ acetone. After extraction, supernatants obtained 
by DMSO and acetone were kept for $3 \mathrm{~h}$ at room temperature in darkness to sediment impurities without degradation of $\mathrm{Chl}$ a, and then measured with a spectrophotometer (GENESYS 10 Bio, Thermo Electron Corporation, Beverly, MA, USA) at 665 and $661 \mathrm{~nm}$, respectively. The $\mathrm{Chl}$ a content was determined using the formula described in [27]. For quantification of phycoerythrin (PE) and phycocyanin (PC), the gametophytic blade was thoroughly grounded in $0.1 \mathrm{M}$ phosphate buffer $(\mathrm{pH}$ 6.8) with a glass homogenizer and centrifuged at $13,200 \times g(12,000 \mathrm{rpm})$ for $10 \mathrm{~min}$ at $4{ }^{\circ} \mathrm{C}$. The resultant supernatant was employed for spectrophotometric determination of the PE $(455,564$ and $592 \mathrm{~nm})$ and PC contents (592, 618 and $645 \mathrm{~nm})$ using the formulae described in [28].

\subsection{Stress Treatments}

Thalli were cultured in $9 \mathrm{~cm}$ dishes (Asnol petri dishes of $90 \mathrm{~mm}$ diameter $\times 20 \mathrm{~mm}$ height; As One Corporation, Osaka, Japan) containing $30 \mathrm{~mL}$ artificial seawater for a week at $15{ }^{\circ} \mathrm{C}$ or $4{ }^{\circ} \mathrm{C}$ in darkness or in light. A razor blade was used to excise $1-\mathrm{mm}^{2}$ gametophytic portions from the tip, middle $(0.8 \mathrm{~cm}$ from the tip) and bottom $(1.6 \mathrm{~cm}$ from the tip) of thalli of 2.0 to $2.4 \mathrm{~cm}$ in length to induce a wounding response. The number of all spores released into the medium was calculated by microscopic observation every day for up to seven days. Explants were also excised from the tip of thalli of various sizes: $0.7,1.7,2.4$ and $3.2 \mathrm{~cm}$ from the tips. Gametogenesis and callus formation were observed in all these samples, sometimes by making vertical sections. To further explore callus formation, non- wounded thalli were incubated at $10,15,20$ and $25^{\circ} \mathrm{C}$ for 36 days as controls. These explants were observed and imaged using an Olympus IX73 light microscope (Olympus, Tokyo, Japan) equipped with an Olympus DP22 camera.

\subsection{Statistics Analysis}

Values are indicated with \pm SD from triplicate experiments except for the cell size measurement that employed a number of cells. A one-way ANOVA followed by a TukeyKramer test was used for multiple comparisons, and significant differences were determined using a cutoff value of $p<0.05$.

\section{Results}

\subsection{Increased Growth of aks Gametophytes}

In the red-colored mutant (Figure 1A), phycoerythrin (PE) was highly accumulated in comparison to in the WT, although the amounts of phycocyanin and chlorophyll a were comparable to those in the WT (Figure 1B). Since it is responsible for the red-colored phenotype of the mutant, this mutant was named akasusabi (aks; red-colored N. yezoensis in Japanese).

To characterize aks, growth rates of monospores under various temperature conditions $\left(0\right.$ to $25^{\circ} \mathrm{C}$ ) were compared with those of WT. Four-week cultivation of monospores indicated that an optimal temperature of $a k s$ and WT was $20^{\circ} \mathrm{C}$ (Figure 2 and Supplementary Figure S1). Aks had a higher growth rate than WT (Figure 2B and Supplementary Figure S1) but discoloration and high growth retardation at $0{ }^{\circ} \mathrm{C}$, and an unusual shrink-and-twist morphology was observed in both WT and aks thalli at $25^{\circ} \mathrm{C}$ (Figure 2A). 

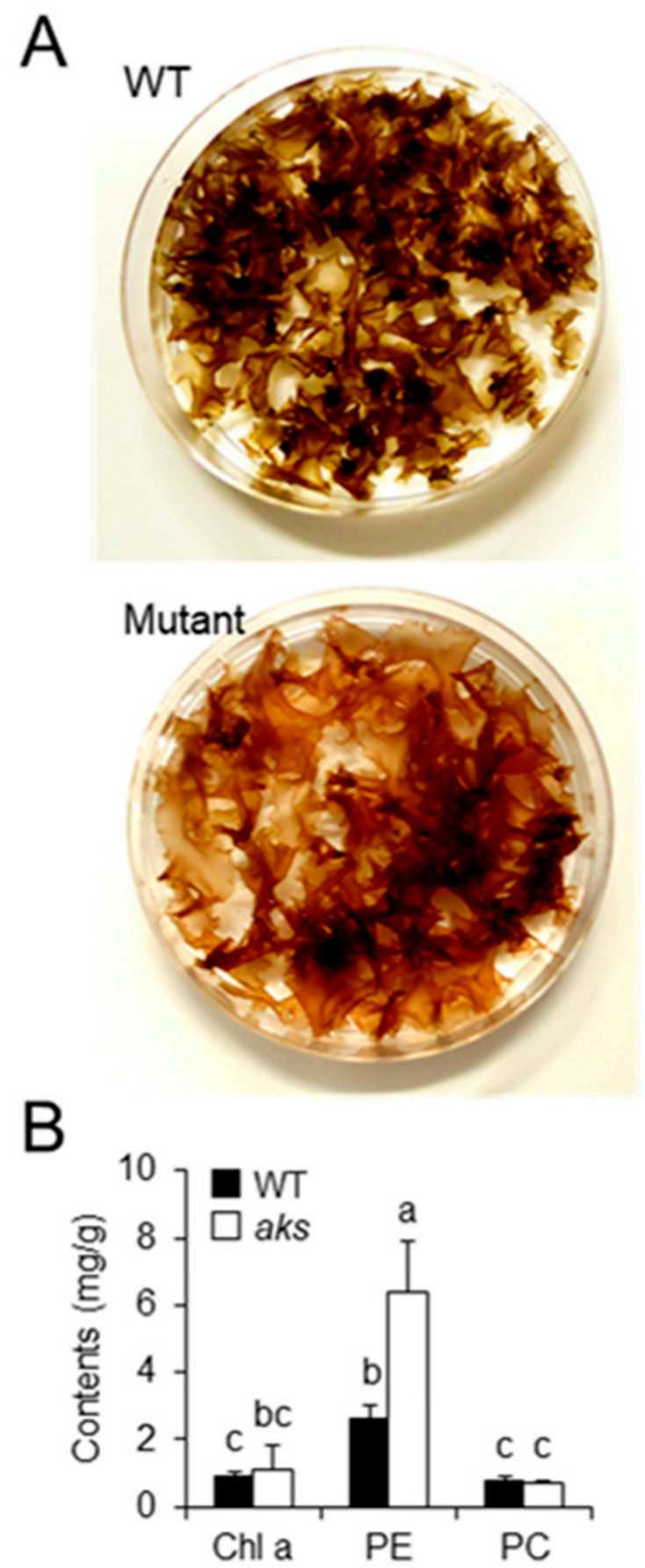

Figure 1. A red-colored mutant aksasusabi (aks) isolated from Neopyropia yezoensis. (A) Comparison of color of gametophytic thalli between the wild type (WT; strain U51) and mutant (B). Pigment compositions between WT (black bars) and mutant named aks (white bars). The error bars indicate the standard deviations $(\mathrm{N}=3)$. Different letters represent the significant difference $(p<0.05)$. Chl a, chlorophyll a; PE, phycoerythrin; PC, phycocyanin. 
A Temperature $\left({ }^{\circ} \mathrm{C}\right)$
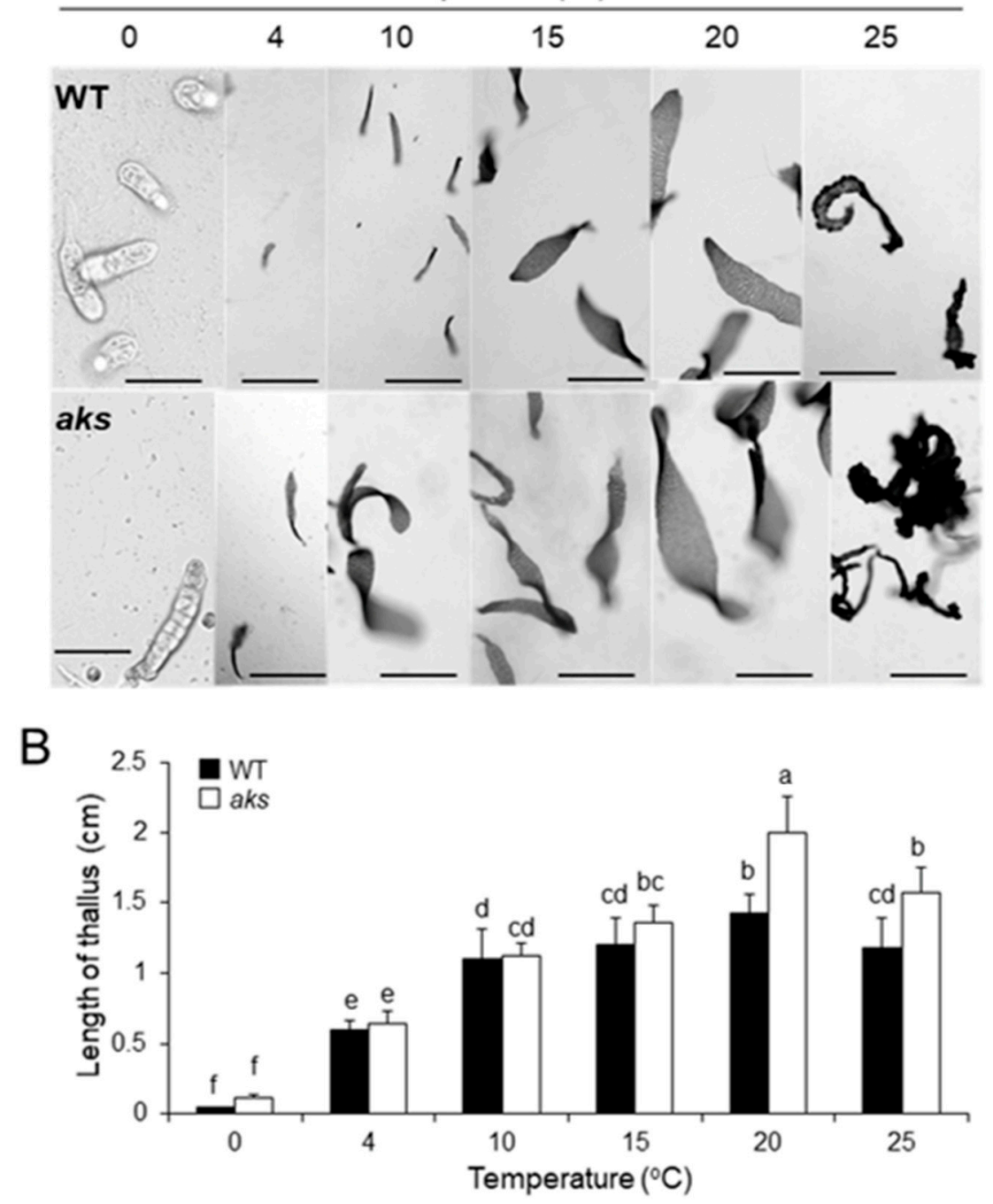

Figure 2. Effects of temperature on growth of gametophytic thalli of WT and aks of Neopyropia yezoensis. (A) Representative images of thalli of WT (upper) and aks (lower) grown from monospores at $0,4,10,15,20$ and $25^{\circ} \mathrm{C}$ for four weeks. Scale bars are $50 \mu \mathrm{m}$ for $0{ }^{\circ} \mathrm{C}$ panels and $500 \mu \mathrm{m}$ for other panels. (B) Lengths of thalli grown from monospores at $0,4,10,15,20$ and $25^{\circ} \mathrm{C}$ for four weeks between WT (black bars) and aks (white bars). The error bars indicate the standard deviations $(\mathrm{N}=3)$. Different letters represent a significant difference $(p<0.05$, and different letters on bars indicate significant differences at $p<0.05$ as tested with ANOVA.

\subsection{Sporophyte Production with Mitotic Defect in aks Carposporangia}

Although the distribution of reproductive sori, male gametangia, was similar between WT and aks (Figure 3A,B), defects in cell division were observed in both male gametangia and carposporangia in aks. Indeed, surface views of reproductive sorus were mostly of 16- and 4-cell clusters for male gametogonia and carposporangia, respectively, in WT (Figure 3C,G, Supplementary Figure S2), whereas aks revealed four- to eight-cell clusters for male gametangia and one- and two-cell clusters for carposporangia in aks (Figure 3D,H, Supplementary Figure S2). Although there is a reduction in the number of anticlinal divisions in aks (Figure 3D), we found all three periclinal cell divisions, forming four-cell layers, in male gametogonia of both WT and aks (Figure 3E,F). In contrast, defects of cell division were severe in carposporangia in aks; vertical section views indicated either none or one anticlinal cell division in aks carposporangia (Figure 3J), which was different from that in WT with triple cell division forming a four-cell layer (Figure 3I). Moreover, the average 
diameter of carposporangial cells was 4.65 to $5.23 \mu \mathrm{m}$ and that of carpospores was $10.26 \mu \mathrm{m}$ in WT (Table 1), indicating that carpospores were enlarged to ca. two-fold after releasing. However, the diameters of both carposporangium cells and carpospores were ca. $11 \mu \mathrm{m}$ in aks (Table 1).

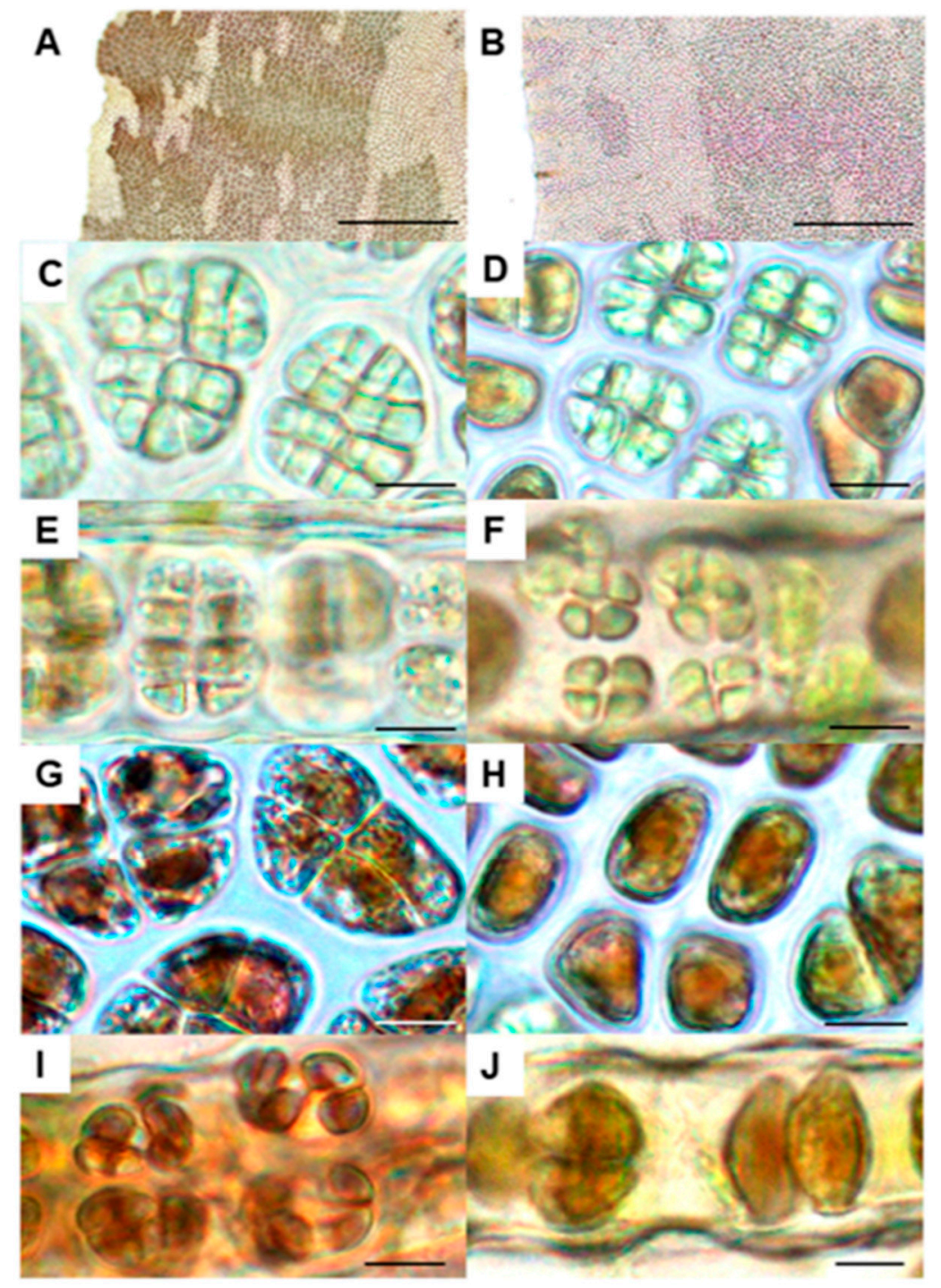

Figure 3. Characteristics of male gametogonia and carpospores in aks. Surface views of reproductive sori produced in thalli $(\mathbf{A}, \mathbf{B})$, male gametogonia $(\mathbf{C}, \mathbf{D})$ and carpospores $(\mathbf{G}, \mathbf{H})$, and transverse views of male gametogonia $(\mathbf{E}, \mathbf{F})$ and carpospores $(\mathbf{I}, \mathbf{J})$ were compared between $\mathrm{WT}(\mathbf{A}, \mathbf{C}, \mathbf{E}, \mathbf{G}, \mathbf{I})$ and aks $(\mathbf{B}, \mathbf{D}, \mathbf{F}, \mathbf{H}, \mathbf{J})$ of Neopyropia yezoensis. Scale bars are $500 \mu \mathrm{m}$ for $(\mathbf{A})$ and $(\mathbf{B})$ and $10 \mu \mathrm{m}$ for $(\mathbf{C}-\mathbf{J})$.

Aks was able to produce conchocelis filaments as well as blades (Figure 4A). In this respect, it is worth noting that vegetative cells of gametophytes were able to produce filamentous conchocelis (Figure 4B). Although these filaments sometimes contained only a few thick cells at their base, resembling conchosporangia, they became narrower distally (Figure 4C). 


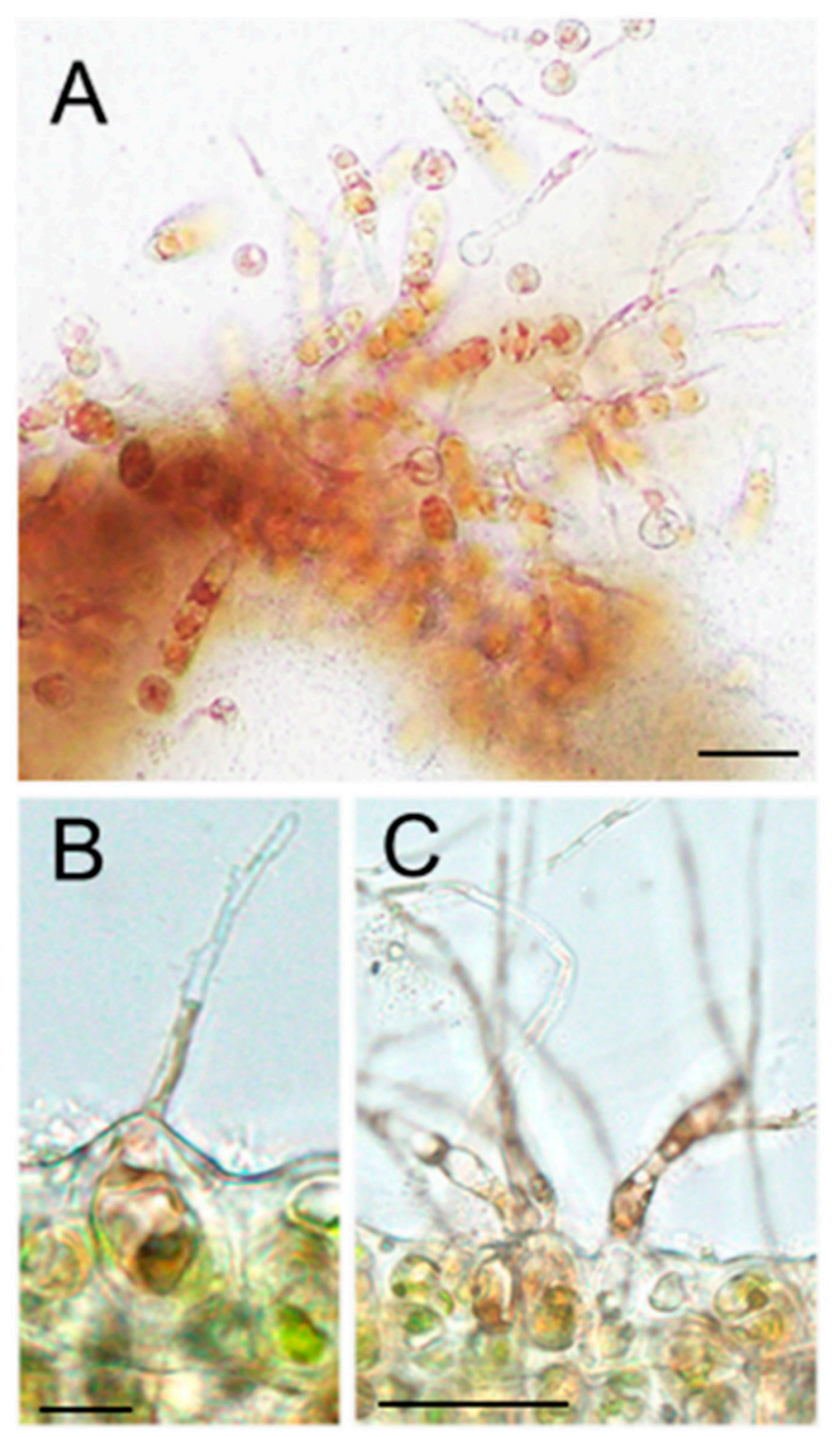

Figure 4. Apogamy in aks. (A) Development of thalli and conchocelis filaments from explants from aks thallus. (B,C) Generation of conchocelis filaments from vegetative cells of $a k s$ blades. Thallus producing conchocelis filaments were cut transversely to observe the origin of conchocelis filaments. Scale bars are $50 \mu \mathrm{m}$ for (A) and (C) and $12 \mu \mathrm{m}$ for (B).

Table 1. Comparison of the diameter $(\mu \mathrm{m})$ of cells in carposporangia and carpospores between WT and aks of Neopyropia yezoensis.

\begin{tabular}{|c|c|c|c|c|c|c|c|}
\hline Strain & \multicolumn{6}{|c|}{ Carposporangia 1} & Carpospores $^{2}$ \\
\hline \multirow{3}{*}{ WT } & \multicolumn{2}{|c|}{ Two-cell layer } & \multicolumn{4}{|c|}{ Four-cell layer } & \\
\hline & Upper & Lower & \multicolumn{4}{|c|}{ Top to bottom } & \\
\hline & $\begin{array}{c}11.4 \pm 2.6 \\
(n=14)\end{array}$ & $\begin{array}{c}9.61 \pm 2.1 \\
(n=14)\end{array}$ & $\begin{array}{c}4.69 \pm 0.6 \\
(n=7)\end{array}$ & $\begin{array}{c}4.65 \pm 0.5 \\
(n=7)\end{array}$ & $\begin{array}{c}4.68 \pm 0.4 \\
(n=7)\end{array}$ & $\begin{array}{c}5.23 \pm 0.6 \\
(n=7)\end{array}$ & $\begin{array}{c}10.26 \pm 1.7 \\
(n=62)\end{array}$ \\
\hline \multirow{3}{*}{$a k s$} & \multirow{2}{*}{\multicolumn{2}{|c|}{ One-cell layer }} & \multicolumn{4}{|c|}{ Two-cell layer } & \\
\hline & & & \multicolumn{2}{|c|}{ Upper } & \multicolumn{2}{|l|}{ Lower } & \\
\hline & \multicolumn{2}{|c|}{$\begin{array}{c}17.5 \pm 3.3 \\
(n=41)\end{array}$} & $\begin{array}{r}11.6 \\
(n\end{array}$ & & \multicolumn{2}{|l|}{$\begin{array}{c}11.18 \pm 1.4 \\
(n=30)\end{array}$} & $\begin{array}{c}11.84 \pm 1.4 \\
(n=76)\end{array}$ \\
\hline
\end{tabular}

${ }^{1}$ Cells in transverse views were measured. ${ }^{2}$ Cells producing a conchocelis filament were measured. Sample numbers (n) are indicated under the values represented with $\pm \mathrm{SD}$. 


\subsection{High Spore Productivity after Wounding Stress in aks}

To address whether the aks mutation affects this wounding stress response, the wounding-dependent production and release of spores were examined using explants excised from three different areas (tip, middle and bottom) of thalli by further incubation at $15^{\circ} \mathrm{C}$. As shown in Figure 5A, the tip explants released a number of spores after a three-day incubation, while a four-day incubation promoted gametogenesis and development of spores to gametophytes and sporophytes (Figure 5B,C). Despite the observation of gametogenesis, apogamy rather than fertilization-dependent production of carpospores was expected, as mentioned in Figure 3. In addition, the release of a large number of spores was observed in all three areas compared to WT, with tip explants showing the highest spore production (Figure 5D).
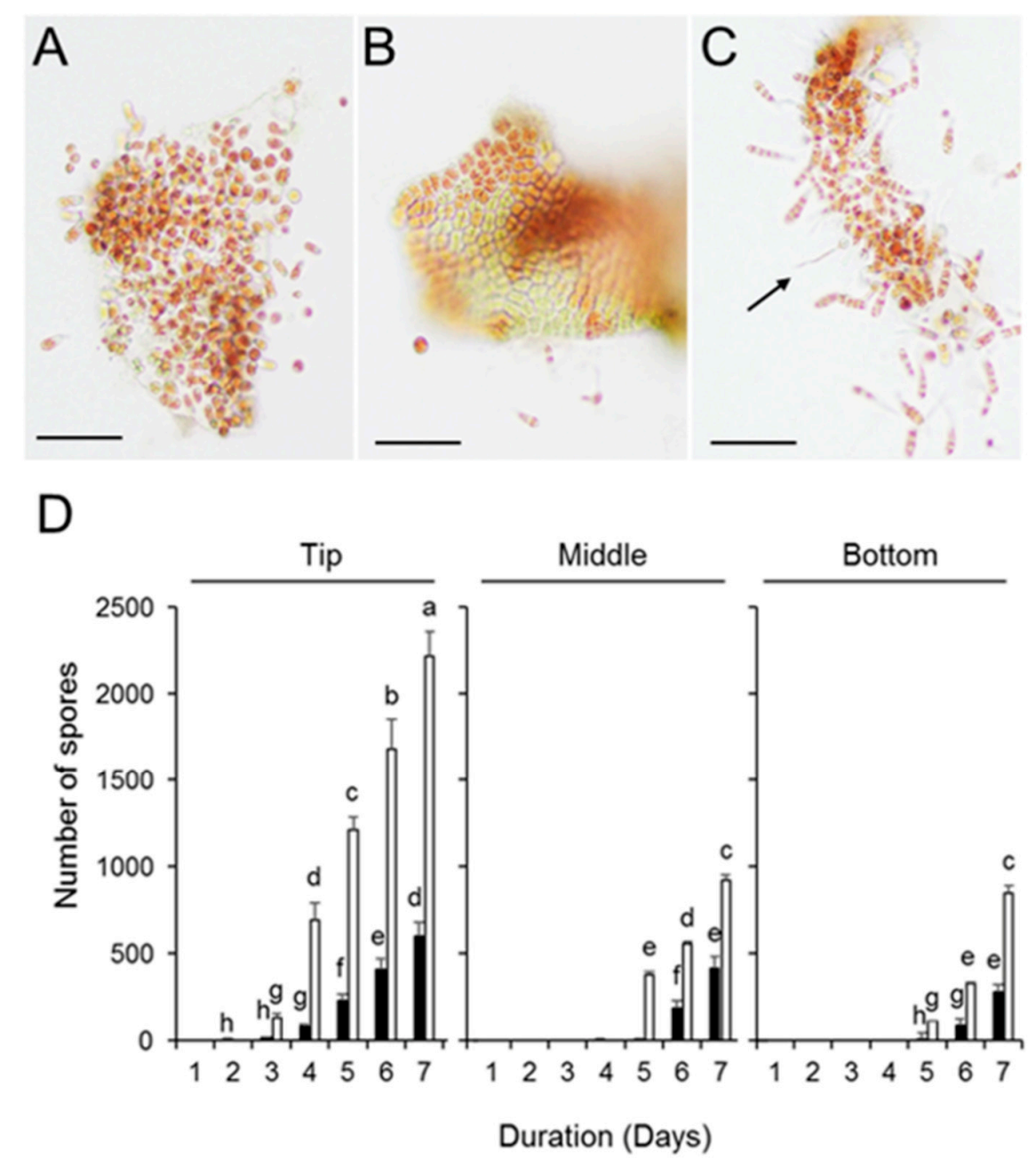

Figure 5. Stimulation of spore discharge by wounding in aks. (A) Wounding-induced discharge of spores three days after excising. At this stage, it was difficult to determine whether a spore was monospore or carpospore. (B) Induction of gametogenesis in wounded thallus four days after excising. Whitish area is male gametogonia. (C) Development of spores released from explants four days after excising. Most of the spores were monospores that developed into gametophytic thalli. Conchocelis filament produced from carpospores generated by apogamy is indicated by arrow. Scale bars are $100 \mu \mathrm{m}$. (D) Comparison of spore releasing between WT (black bars) and aks (white bars). Explants were excised from tip, middle $(0.8 \mathrm{~cm}$ from the tip) and bottom $(1.6 \mathrm{~cm}$ from the tip) of $2.4 \mathrm{~cm}$ thalli and incubated for seven days. The numbers of discharged spores ( $\mathrm{Y}$ axis) were counted every day as indicated on the $\mathrm{X}$ axis. Error bars indicate the standard deviation of triplicate experiments $(\mathrm{N}=3)$, and different letters on bars indicate significant differences at $p<0.05$ as tested with ANOVA. 


\subsection{Heat Stress Inducibility of Callus Formation in aks}

Whole aks thalli without wounding incubated at $25^{\circ} \mathrm{C}$ for 36 days also produced calluses (Figure 6A) and were responsible for the "shrink-and-twist" morphology (Figure 2A and Supplementary Figure S3) revealed by the formation of multilayers of vegetative cells (Figure 6B and Supplementary Figure S3). Moreover, calluses of aks produced gametophytes with normal morphology (Figure 6C) similar to WT [29]. Although the frequency of callus production per thallus was lower than that of WT (Figure 5D), calluses were produced at 10 and $20^{\circ} \mathrm{C}$ in addition to $25^{\circ} \mathrm{C}$ (Figure 6E), in contrast to WT where calluses were produced only at $25^{\circ} \mathrm{C}$ [29]. Thus, the aks mutation alters the frequency and temperature dependency of callus production, although callus-derived generation of gametophytes is not affected.
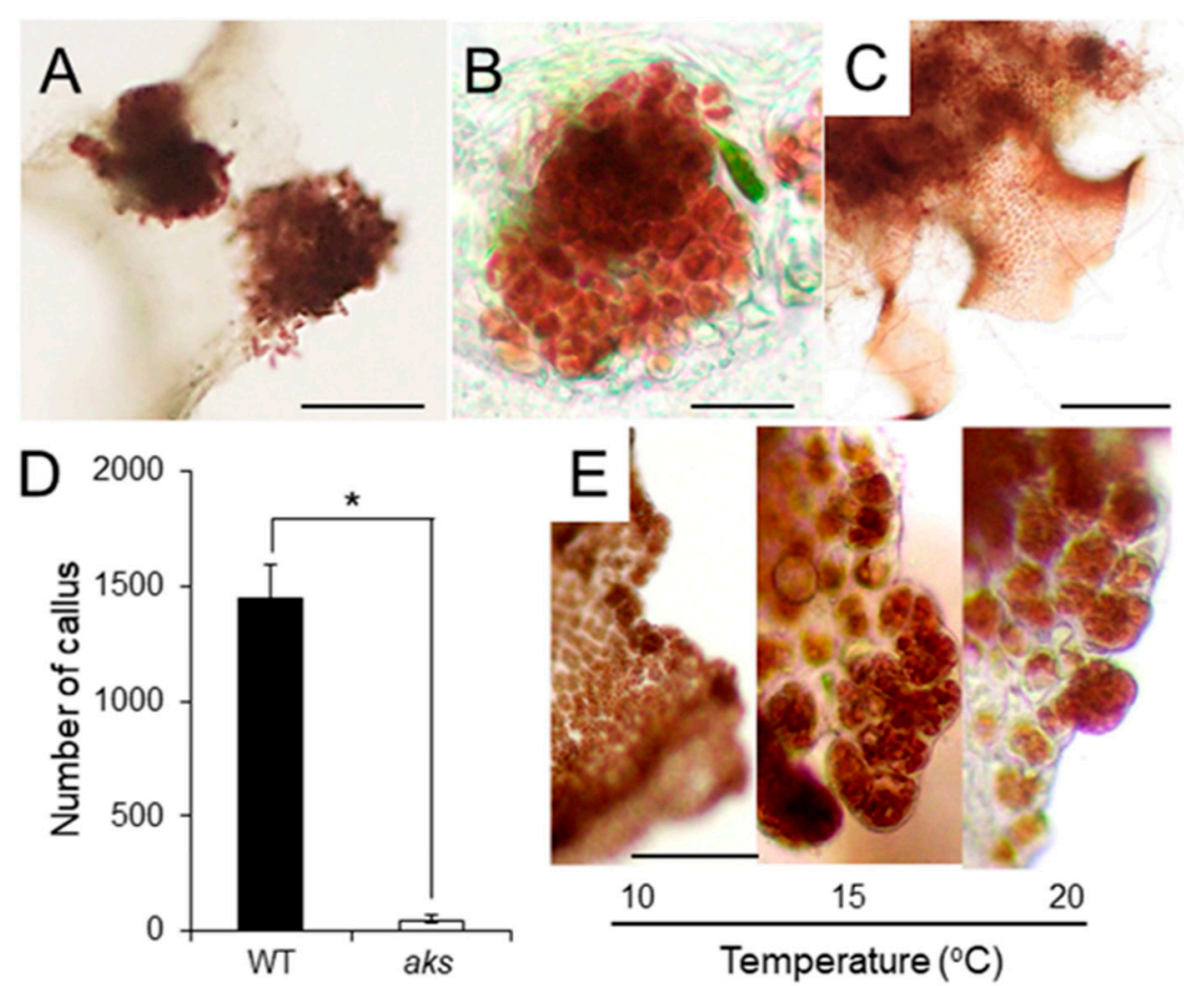

Figure 6. Heat stress-induced callus production in non-wounded aks thalli. (A) Production of callus on thallus incubated at $25^{\circ} \mathrm{C}$ for 36 days. (B) Transverse view of callus. (C) Development of normal thallus from callus. (D) Comparison of frequency of callus formation per thallus at $25^{\circ} \mathrm{C}$ for 36 days between WT (black bar) and aks (white bar). Error bars indicate the standard deviation of triplicate experiments $(\mathrm{N}=3)$ and an asterisk $\left({ }^{*}\right)$ indicates a significant difference at $p<0.05$ as tested with ANOVA. (E) Callus production under broad ranges of temperatures $\left(10,15\right.$ and $\left.20^{\circ} \mathrm{C}\right)$. Scale bars are $250 \mu \mathrm{m}$ for (A), $100 \mu \mathrm{m}$ for $(\mathbf{B})$ and (C) and $250 \mu \mathrm{m}$ for (E).

\section{Discussion}

Our characterization of aks derived from N. yezoensis strain U51 indicated defects in the maturation of carposporangia and apogamy to generate carpospores from vegetative cells of gametophytes for production of sporophytes. In seaweeds, only two life-cycle mutants, oro and sam, have been isolated to date from the brown alga E. siliculosus [23,24], which do not represent apogamy from vegetative cells because of the production of gametophytes from unfertilized gametes, although these gametes usually develop to parthenogametophytes by parthenogenesis $[6,22,23])$. Therefore, we concluded that aks is the first life-cycle mutant in Rhodophyta and the first apogamous mutant in macroalgae.

Table 1 indicates similarity in the diameters of carposporangium cells and carpospores in aks. If carpospores are released from carposporangia in aks, these should be enlarged in 
seawater (see WT in Table 1); however, no enlarged spores appeared (Table 1), although fertilization occurs in aks (Figure 3D,H, Supplementary Figure S2). Thus, aks cannot produce carpospores in carposporangia via mitosis, suggesting a possibility that carpospores to generate conchocelis filaments might be produced in an alternative way different from maturation of carposporangia. We, therefore, proposed that the aks mutation brings apogamy, the generation of sporophytes from gametophytes without fertilization $[19,20]$, to overcome the lack of carpospore production by defects in maturation of carposporangia through mitotic cell divisions, which is responsible for the production of conchocelis filaments in aks.

However, since gametogenesis and fertilization occurred, sexual reproductive processes to produce carpospores were not fully suppressed. At present, little is known about the relationship between apogamy and defects in the maturation of male gametagonia and carposporangia. Alternatively, it is possible to propose a stepwise generation of aks causing defects in carpospore production in an apogamous strain or acquisition of apogamous ability in a carposporangium-immature strain. Although artificial inactivation of carpospore production in $N$. yezoensis is technically impossible at present, genetic analysis of aks is expected to partly contribute to answering these questions by, for instance, confirmation of heritability of the aks mutation.

Apogamy is defined as gametophyte-to-sporophyte transition without fertilization or chromosome duplication $[19,20]$. Thus, it is a question of whether aks produces haploid sporophytes. As far as we observed, sporophytes of aks produced conchosporophytes that released unicellular conchospores as gametophytic cells to generate haploid gametophytic thalli (data not shown), suggesting a possibility that aks sporophytes are diploid. Recently, it has been observed that vegetative cells of male and female gametophytes have the potential to produce sporophytes via chromosome duplication in Neopyropia haitanensis [30,31], which is different from so-called apogamy and parthenogenesis. As we defined these phenomena as diploid apogamy [32], we proposed that aks can generate diploid sporophytes from vegetative cells via diploid apogamy with chromosome duplication. Karyotypic analysis of chromosome numbers in aks sporophytes should be necessary to confirm this prediction. One of the remarkable characteristics of $a k s$ was a higher growth rate than that of WT, while the optimal temperature for growth was the same for both WT and aks. It has been reported that reproductive sterility resulted in acceleration of the growth rate in the sterile mutant of the green alga Ulva rigida, for which the contribution of adenosine triphosphate (ATP) and nicotinamide adenine dinucleotide phosphate (NADP) produced by photosynthesis on lipid synthesis was proposed to support faster growth $[33,34]$.

We observed discoloration of thalli at $0{ }^{\circ} \mathrm{C}$ with strong growth retardation, and formation of the "shrink-and-twist" morphology, by callus formation at $25^{\circ} \mathrm{C}$ in both WT and aks. Although discoloration might be due to the cold-inducible inhibition of nitrogen, uptake resulting in destruction of phycobilisomes [35], little is known about how callus formation is induced by heat stress. Heat stress disrupts the direction of cell division, and such a non-polarized random cell division produces calluses. Thus, elucidation of the mechanisms of callus formation could provide insights into the regulatory mechanisms of single-cell-layered blade formation. Moreover, production of gametophytic thalli from calluses was observed, indicating that production of calluses in aks could be a method of asexual reproduction [29]

Wounding and heat stress promote asexual reproduction in aks, but the frequency of promotion was influenced differently by these stresses, with enhancement of the wounding inducibility of spore production (Figure 5D) and attenuation of heat-dependent callus production. Little is known about the relationship between these two asexual strategies in N. yezoensis.

We also observed that wound stress enhanced the production of monospores and apogamous carpospores. These findings indicated that wound stress promotes the life cycle trade-off to reset the timing of both asexual and sexual reproductive phases in aks. Although this has been observed in wounded WT thalli [29], the aks mutation strongly enhanced the wound-dependent productivity of these spores compared to WT, suggest- 
ing the high frequency of the life cycle trade-off in wound-stressed aks. Thus, we proposed that productivity of spores by the life cycle trade-off in aks is basically high, which is further accelerated by wounding, although it is unclear whether enhanced spore production depends on the increase in the sensitivity to wounding or strength of stress response in aks. Moreover, as in WT [29], we also observed that three-day dark treatment of aks prior to wounding resulted in the enhancement of asexual life cycle trade-off for monospore production and apogamy for the fertilization-independent gametophyte-to-sporophyte transition (data not shown), indicating that the aks mutation has no effect on the ability of dark-enhanced spore formation. Since these findings suggest that dark treatment might increase the intrinsic potential of monospore production and apogamy in N. yezoensis, it is possible that the activities of factors involved in these events might be influenced by the dark. Identification of a dark-sensitive factor contributes to understanding the regulatory mechanisms of monospore production and apogamy since little is known about the factors involved in asexual life cycle trade-off and apogamy in N. yezoensis to date. In fact, promotion of gametogenesis by wounding or wounding plus heat stress has also been observed in the green algal genus Ulva [33,34,36-39]. Therefore, comparative analysis of the wounding-dependent gametogenesis between red and green alga might provide insight into regulatory mechanisms of the life cycle trade-off in macroalgae.

Based on the above findings, it is proposed that a gene(s) responsible for the aks phenotypes is involved in the gametophyte-to-sporophyte transition in N. yezoensis. Factors regulating gametophyte-to-sporophyte transition in terrestrial plants have been identified, indicating that polycomb repressive complex 2 (PRC2) and bell-like 1 (BELL1) of the threeamino acid-length extension class homeodomain (TALE-HD) transcription factors regulate the transition from gametophyte to sporophyte in the moss Physcomitrium patens (formerly Physcomitrella patens) [40-42], where gametophyte identity is maintained through the repression of a gene encoding BELL1 by PRC2 containing curly leaf and fertilization-independent endosperm. In fact, it has already been demonstrated that red algae including N. yezoensis and green algae have homologs of BELL1 transcription factors [21,43,44], and conservation of components of PRC2 in red and green algae has been demonstrated [45-48]. Thus, the similarity in the regulation of the gametophyte-to-sporophyte transition is proposed between terrestrial plants and algae. It is supported by recent findings in the brown alga E. siliculosus, in which repression of genes encoding TALE-HD transcription factors resulted in maintenance of gametophyte identity [23]. In addition, we have confirmed the presence of genes encoding BELL1 homologs in N. yezoensis [21], although the functions of these genes remain to be elucidated. Future research should investigate whether $A K S$ encodes a member of a PRC2 or BELL1 transcription factor, to provide novel insights into the regulatory mechanisms of gametophyte-to-sporophyte transition in macroalgae.

\section{Conclusions}

We isolated and characterized aks, that is, the first life-cycle mutant in Bangiales. There are two main phenotypes in aks in addition to the red coloration and high-growth property. One is employment of apogamy to overcome the lack of maturation of carposporangia to produce carpospores developing directly into sporophytes, while the other is enhancement in gametogenesis, frequency of the life cycle trade-off and apogamy by responding to wounding and heat stress. These findings reveal that aks is indispensable material for elucidation of the regulatory mechanisms of generation transition in the life cycle and reproductive events like gametogenesis and monospore production in Rhodophyta. Studies on factors promoting apogamy, monospore production and callus formation in aks will present major opportunities to shed light on the regulatory mechanisms of generation transition and flexible promotion of life cycle trade-off by environmental stresses in macroalgae.

Supplementary Materials: The following are available online at https: / www.mdpi.com/article / 10.3390 / phycology1010002/s1, Figure S1: Comparison of time courses of changes in growth rate of thalli in WT (A) and aks (B) under various temperature, Figure S2: Defects in maturation of male 
gametogania and carposporangia in aks, and Figure S3: Callus production leading the shrink-andtwist morphology under heat stress conditions in aks.

Author Contributions: Conceptualization, methodology, investigation, formal analysis, data curation, validation, writing-original draft preparation and writing-review and editing, K.M.; methodology and investigation, T.M.; resources, methodology and investigation, Y.Y. All authors have read and agreed to the published version of the manuscript.

Funding: This work was supported in part by KAKENHI grant (15H04539) from MEXT.

Institutional Review Board Statement: Not applicable.

Informed Consent Statement: Not applicable.

Data Availability Statement: Data are contained within the article.

Conflicts of Interest: The authors declare no conflict of interest.

\section{References}

1. Friedman, W.E. One genome, two ontogenies. Science 2013, 339, 1045-1046. [CrossRef]

2. Bowman, J.L.; Sakakibara, K.; Furumizu, C.; Dierschke, T. Evolution in the cycles of life. Annu. Rev. Genet. 2016, 50, 133-154. [CrossRef]

3. Blouin, N.A.; Brodie, J.A.; Grossman, A.C.; Xu, P.; Brawley, S.H. Porphyra: A marine crop shaped by stress. Trends Plant Sci. 2011, 16, 29-37. [CrossRef]

4. Takahashi, M.; Mikami, K. Oxidative stress promotes asexual reproduction and apogamy in the red seaweed Pyropia yezoensis. Front. Plant. Sci. 2017, 8, 62. [CrossRef]

5. Drew, K.M. Conchocelis-phase in the life-history of Porphyra umbilicalis (L.) Kütz. Nature 1949, 164, 748-749. [CrossRef]

6. Cock, J.M.; Godfroy, O.; Macaisne, N.; Peters, A.F.; Coelho, S.M. Evolution and regulation of complex life cycles: A brown algal perspective. Curr. Opin. Plant Biol. 2014, 17, 1-6. [CrossRef] [PubMed]

7. Liu, X.; Bogaert, K.; Engelen, A.H.; Leliaert, F.; Roleda, M.Y.; de Clerck, O. Seaweed reproductive biology: Environmental and genetic controls. Bot. Mar. 2017, 60, 89-108. [CrossRef]

8. Ma, J.H.; Miura, A. Observations of the nuclear division in the conchospores and their germlings in Porphyra yezoensis Ueda. Jpn. J. Phycol. 1984, 32, 373-378.

9. Ohme, M.; Kunifuji, Y.; Miura, A. Cross experiments of the color mutants in Porphyra yezoensis Ueda. Jpn. J. Phycol. 1986, 34, 101-106.

10. Burzycki, G.M.; Waaland, J.R. On the position of meiosis in the life history of Porphyra torta. Bot. Mar. 1987, 30, 5-10. [CrossRef]

11. Ohme, M.; Miura, A. Tetrad analysis in conchospore germlings of Porphyra yezoensis (Rhodophyta, Bangiales). Plant Sci. 1988, 57, 135-140. [CrossRef]

12. Tseng, C.K.; Sun, A. Studies on the alternation of the nuclear phases and chromosome numbers in the life history of some species of Porphyra from China. Bot. Mar. 1989, 32, 1-8. [CrossRef]

13. Mitman, G.G.; van der Meer, J.P. Meiosis, blade development, and sex determination in Porphyra purpurea (Rhodophyta). J. Phycol. 1994, 30, 147-159. [CrossRef]

14. Yan, X.; Li, L.; Aruga, Y. Genetic analysis of the position of meiosis in Porphyra haitanensis Chang et Zheng (Bangiales, Rhodophyta). J. Appl. Phycol. 2005, 17, 467-473. [CrossRef]

15. Wang, J.; Dai, J.; Zhang, Y. Nuclear division of the vegetative cells, conchosporangial cells and conchospores of Porphyra yezoensis (Bangiales, Rhodophyta). Phycol. Res. 2006, 54, 201-207. [CrossRef]

16. Shimizu, A.; Morishima, K.; Kobayashi, M.; Kunimoto, M.; Nakayama, I. Identification of Porphyra yezoensis (Rhodophyta) meiosis by DNA quantification using confocal laser scanning microscopy. J. Appl. Phycol. 2007, 20, 83-88. [CrossRef]

17. Yan, X.; Huang, M. Identification of Porphyra haitanensis (Banglales, Rhodophyta) meiosis by simple sequence repeat markers. J. Phycol. 2010, 46, 982-986. [CrossRef]

18. Strasburger, E. The periodic reduction of the number of the chromosomes in the life history of living organisms. Ann. Bot. 1984, 8 , 281-316.

19. Mehra, P.N.; Sulklyan, D.S. In vitro studies on apogamy, apospory and controlled differentiation of rhizome segments of the fern, Ampelopteris prolifera (Retz.) Copel. Bot. J. Linn. Soc. 1969, 62, 431-443. [CrossRef]

20. Bell, P.R. Apospory and apogamy: Implications for understanding the plant life cycle. Int. J. Plant Sci. 1992, 153 Pt 2, S123-S136. [CrossRef]

21. Mikami, K.; Li, C.; Irie, R.; Hama, Y. A unique life cycle transition in the red seaweed Pyropia yezoensis depends on apospory. Commun. Biol. 2019, 2, 229. [CrossRef]

22. Coelho, S.M.; Godfroy, O.; Arun, A.; Le Corguillé, G.; Peters, A.F.; Cock, J.M. OUROBOROS is a master regulator of the gametophyte to sporophyte life cycle transition in the brown alga Ectocarpus. Proc. Natl. Acad. Sci. USA 2011, 108, 11518-11523. [CrossRef] [PubMed] 
23. Arun, A.; Coelho, A.M.; Peters, A.F.; Bourdareau, S.; Pérès, L.; Scornet, D.; Strittmatter, M.; Lipinska, A.P.; Yao, H.; Godfroy, O.; et al. Convergent recruitment of TALE homeodomain life cycle regulators to direct sporophyte development in land plants and brown algae. Elife 2019, 8, e43101. [CrossRef]

24. van der Meer, J.P.; Patwary, M.U.; Bird, C.J. Genetics of Gracilaria tikvahiae (Rhodophyceae). X. Studies on a bisexual clone. J. Phycol. 1984, 20, 42-46. [CrossRef]

25. van der Meer, J.P. Genetics of Gracilaria tikvahiae (Rhodophyceae). XI. Further characterization of a bisexual mutant. J. Phycol. 1986, 22, 151-158.

26. Li, C.; Ariga, I.; Mikami, K. Difference in nitrogen starvation-inducible expression patterns among phylogenetically diverse ammonium transporter genes in the red seaweed Pyropia yezoensis. Am. J. Plant Sci. 2019, 10, 1325-1349. [CrossRef]

27. Seely, G.R.; Duncan, M.J.; Vidaver, W.E. Preparative and analytical extraction of pigments from brown algae with dimethyl sulfoxide. Mar. Biol. 1972, 12, 184-188. [CrossRef]

28. Beer, S.; Eshel, A. Determining phycoerythrin and phycocyanin concentrations in aqueous crude extracts on red algae. Mar. Freshw. Res. 1985, 36, 785-792. [CrossRef]

29. Suda, M.; Mikami, K. Reproductive responses to wounding and heat stress in gametophytic thalli of the red alga Pyropia yezoensis. Front. Mar. Sci. 2020, 7, 394. [CrossRef]

30. Zhong, C.; Aruga, Y.; Yan, X. Morphogenesis and spontaneous chromosome doubling during the parthenogenetic development of haploid female gametophytes in Pyropia haitanensis (Bangiales, Rhodophyta). J. Appl. Phycol. 2019, 31, 2729-2741. [CrossRef]

31. Zhong, C.; Yan, X. Haploid spontaneous diploidization during apogamy of male gametophytes in Pyropia haitanensis (Bangiales, Rhodophyta). J. Appl. Phycol. 2020, 32, 1395-1403. [CrossRef]

32. Mikami, K. Diploid apogamy in red algal species of the genus Pyropia. J. Aquat. Res. Mar. Sci. 2019, 2019, $206-208$.

33. Gao, G.; Clare, A.S.; Rose, C.; Caldwell, G.S. Reproductive sterility increases the capacity to exploit the green seaweed Ulva rigida for commercial applications. Algal Res. 2017, 24, 64-71. [CrossRef]

34. Gao, G.; Clare, A.S.; Rose, C.; Caldwell, G.C. Intrinsic and extrinsic control of reproduction in the green tide-forming alga, Ulva rigida. Environ. Exp. Bot. 2017, 139, 14-22. [CrossRef]

35. Takahashi, M.; Kumari, P.; Li, C.; Mikami, K. Low temperature causes discoloration by repressing growth and nitrogen transporter gene expression in the edible red alga Pyropia yezoensis. Mar. Environ. Res. 2020, 159, 105004. [CrossRef] [PubMed]

36. Gao, S.; Chen, X.; Yi, Q.; Wang, G.; Pan, G.; Lin, A.; Peng, G. A strategy for the proliferation of Ulva prolifera, main causative species of green tides, with formation of sporangia by fragmentation. PLoS ONE 2010, 5, e8571. [CrossRef] [PubMed]

37. Wichard, T.; Oertel, W. Gametogenesis and gamete release of Ulva mutabilis and Ulva lactuca (chlorophyta): Regulatory effects and chemical characterization of the "swarming inhibitor". J. Phycol. 2010, 46, 2248-2259. [CrossRef]

38. Vesty, E.F.; Kessler, R.W.; Wichard, T.; Coates, J.C. Regulation of gametogenesis and zoosporogenesis in Ulva linza (Chlorophyta): Comparison with Ulva mutabilis and potential for laboratory culture. Front. Plant Sci. 2015, 6, 15. [CrossRef]

39. Katsaros, C.; Weiss, A.; Llangos, I.; Theodorou, I.; Wichard, T. Cell structure and microtubule organisation during gametogenesis of Ulva mutabilis Føyn (Chlorophyta). Bot. Mar. 2017, 60, 123-135. [CrossRef]

40. Mosquna, A.; Katz, A.; Decker, E.L.; Rensing, S.A.; Reski, R.; Ohad, N. Regulation of stem cell maintenance by the Polycomb protein FIE has been conserved during land plant evolution. Development 2009, 136, 2433-2444. [CrossRef]

41. Okano, Y.; Aono, N.; Hiwatashi, Y.; Murata, T.; Nishiyama, T.; Ishikawa, T.; Kubo, M.; Hasebe, M. A polycomb repressive complex 2 gene regulates apogamy and gives evolutionary insights into early land plant evolution. Proc. Natl. Acad. Sci. USA 2009, 106, 16321-16326. [CrossRef]

42. Horst, N.A.; Katz, A.; Pereman, I.; Decker, E.L.; Ohad, N.; Reski, R. A single homeobox gene triggers phase transition, embryogenesis and asexual reproduction. Nat. Plants 2016, 2, 15209. [CrossRef] [PubMed]

43. Mukherjee, M.; Brocchierin, L. A comprehensive classification and evolutionary analysis of plant homeobox genes. Mol. Biol. Evol. 2009, 26, 2775-2794. [CrossRef] [PubMed]

44. Joo, S.; Wang, M.H.; Lui, G.; Lee, J.; Barnas, A.; Kim, E.; Sudek, S.; Worden, A.Z.; Lee, J.-H. Common ancestry of heterodimerizing TALE homeobox transcription factors across Metazoa and Archaeplastida. BMC Biol. 2018, 16, 136. [CrossRef] [PubMed]

45. Shaver, S.; Casas-Mollano, J.A.; Cerny, R.H.; Cerutti, H. Origin of the polycomb repressive complex 2 and gene silencing by an $\mathrm{E}(\mathrm{z})$ homolog in the unicellular alga Chlamydomonas. Epigenetics 2010, 5, 301-312. [CrossRef] [PubMed]

46. Huang, Y.; Chen, D.-H.; Liu, B.-Y.; Shen, W.-H.; Ruan, Y. Conservation and diversification of polycomb repressive complex 2 (PRC2) proteins in the green lineage. Brief. Funct. Genom. 2017, 16, 106-119. [CrossRef] [PubMed]

47. Mikulski, P.; Komarynets, O.; Fachinelli, F.; Weber, A.P.M.; Schubert, D. Characterization of the Polycomb-group mark H3K27me3 in unicellular algae. Front. Plant Sci. 2017, 8, 607. [CrossRef]

48. Schubert, D. Evolution of Polycomb-group function in the green lineage. F1000Res 2019, 8. [CrossRef] 